\title{
12 The vitality of the Dutch Senate
}

\author{
Two centuries of reforms and \\ staying in power
}

Bert van den Braak

\section{Introduction}

The Dutch Senate (Eerste Kamer, lit. first chamber) has not only survived several attacks on its existence but also managed to covertly increase its political power in the process (Broeksteeg 2007). This chapter aims to explain how and why the Senate has been able to remain a major and respected force in Dutch politics.

To understand the history of the Dutch Senate, it should first be clarified why the Netherlands, which regained its independence after the Napoleonic era in 1813, has a bicameral system at all. What role did the 1815 constitution reserve for the Senate? What specific role would the Senate actually play? Was it a bulwark for the ruling class or an obstacle for legislation considered either too liberal or too democratic - or did the Senate make positive contributions as well? If so, what were they? Furthermore, I will analyse how the Senate managed to adapt to new situations and overcome the frequent accusations of its being superfluous and undemocratic. There were several instances, e.g. in 1830, 1848, 1918, 1922 and the 1960s, when the position of the Senate seemed to be in jeopardy. Why was the Senate not abolished at those times? Perhaps the existence of the Senate was not under nearly as big a threat as is commonly believed.

A major aspect of my analysis concerns the composition of the Senate. How did the background of the members of both the Senate and the House of Representatives differ? In many countries, regional representation is an important reason for the existence of an upper house. Was this the case in the Netherlands as well? And in what way, if any, are the provinces of the Netherlands and the Senate linked?

There has always been an ongoing discussion about the necessity of a senate in the Netherlands. The main conclusion of my 1998 study on the Dutch Senate was that the institution would not be abolished, and politicians would do better to change the discussion to how the role of the Senate could be improved (Van den Braak 1998). This is also what would eventually happen. I would still agree with my conclusion that the Senate could not be abolished, but in the years after the 1990s, there were several developments that should be considered, such as political fragmentation and instability and occasional opposing majorities in the House of Representatives and the Senate. At a later point, I will discuss the functioning of the parliamentary system in recent years. A final question we will consider is 
how likely it is that the current system will be changed and what possibilities exist to facilitate that change, given the fact that constitutional reform in the Netherlands is a long and laborious process.

\section{The workings of the Senate, 1815-1923}

In the nineteenth century, bicameralism was generally seen as the 'normal' parliamentary model, used by most semi-democratic nations. For that reason, the Dutch unicameral Parliament, instituted in 1814 and called States-General in remembrance of the former Dutch Republic, was rather exceptional (Blom 1992; cf. Oddens, this volume). However, after the Netherlands was unified with the Southern Netherlands and Luxembourg in 1815, a constitutional commission was set up and concluded that there was good reason to divide Parliament into two houses (cf. Witte, this volume). The commission referred to the parliaments of major countries, such as those of France and the United Kingdom.

The first purpose of the second (upper) house was to create an institution that could prevent hasty law reforms and 'evil' (De Vries 2000). Those tasked for this job were appointed by the king (Beekelaar \& De Schepper 1992). Any eminent man from the age of 40 could be appointed as a member for life. Thus, the Senate was not a house reserved for the nobility, as, for example, the British House of Lords was. Distinguished mayors in the North and landowners could be members as well. Nobility had never-save for in the South - played a prominent role in the North. In the Southern (Austrian) part of the Netherlands, nobles had been closely connected to the Austrian imperial court.

By creating this new house, King William (crowned on March 16, 1815 before which he was only a sovereign) achieved what he wanted. This meant that the Senate could form a bulwark for him against the elected House of Representatives, which had the right to put forward bills - or the right of initiative. Belgian nobles would be incorporated in the new governmental system and the king could appoint and - as would become clear some years later - sack whomever he wanted (Van den Braak 1998).

In general, the Senate played the political role the king had intended, but dissatisfaction soon grew among the Belgian members (Witte, this volume). The few bills that were rejected were mostly initiated by Belgian MPs and dealt with taxes, trade, freedom of press, and the judicial system. This discontent could be linked to the general distress among Belgians with Northern domination and its free trade policy. The upper house appeared to be a bulwark not only for the king but also for the Northern part of the kingdom. Although the number of inhabitants in the South was much higher than that in the North, it had fewer representatives in Parliament, both in the Senate and in the House of Representatives. In the Senate, there were always some Southern members who remained loyal to the king and voted accordingly. Discontent in the South in 1830 ended in the separation of North and South and the emergence of the Kingdom of Belgium. Nevertheless, that did not mean the end of the Senate. 
It took until 1840 for the separation to become anchored in a new constitution because it was not before 1839 that King William I accepted the cessation of the Southern half of his country. The constitution of 1815 stated that constitutional reform had to pass both houses twice. After it passed the House of Representatives for the second time, the new constitution doubled the number of members of the chamber and stipulated that it would act as a sort of constituent assembly.

Only a few (newly chosen) MPs advocated the abolition of the Senate. Johan Thorbecke, professor at Leiden University and future leader of the liberal (democratic) opposition, asserted in his writings that he saw no reason for the existence of a senate at all. Guillaume Groen van Prinsterer, the leader of an even smaller Protestant group, said that he considered the Dutch Senate a failed facsimile of the British House of Lords. Others pointed out the high costs. Still, the opponents were a minority. In general, it was accepted that only the king himself could put forward a constitutional reform. Since the king was satisfied with the existence of the Senate, no such proposal was to be expected, and the Senate's position was not in danger.

Yet in 1848, King William II, impressed as he was by the news of revolutionary movements in Germany and the stirrings of turmoil in Holland, 'went from being a conservative to a liberal in one night', as the popular saying goes. Thorbecke was asked to lead a commission tasked with creating a draft for constitutional reform. Beside ministerial responsibility, the proposed reforms included the possibility to dissolve Parliament and call new elections, the introduction of a yearly budget, Parliament's right to inquiry, the right of the House of Representatives to amend bills, and direct elections for both houses. As in 1840, all these reforms had to pass both houses twice, including the still staunchly conservative Senate.

In both houses of Parliament, several members opposed the king's political shift. These members wanted to maintain the strong position for the king, including his right to nominate the members of the Senate. Abolition of the Senate certainly stood no chance. In order to secure a majority for other, more important reforms, the liberals had to concede to a less democratic electoral system for the Senate. That electoral system was a copy of the one that had been used for electing the House of Representatives before 1848. Members of the Senate would be elected by the States-Provincial, the provincial parliaments, but only those who paid the highest taxes were eligible. The thirty-nine members were elected for a nine-year term, and there would be new elections for one-third of the Senate every three years.

The voting results in the Senate were very close. To prevent a negative outcome, the king had asked some elderly members to step down and appointed several new, more reform-minded members in advance. After a tie in the first vote, he persuaded one member, one of his own court officials, to change his vote to pass the first round. Before the vote for the second reading, a few new reform-minded members were again appointed. The reform was accepted with a clear majority. In 1849 a reformed Senate emerged (Van den Braak 1998). In its defence, Minister Dirk Donker Curtius stated that the main goal of the Senate was not to establish the good but to prevent 'evil'. 
In 1849, a moderate liberal era started. In the years 1850-1851, Thorbecke, as home secretary, successfully defended legislation to implement constitutional reforms, such as laws on municipal and provincial government, parliamentary inquiries, and the new electoral laws. None of these governmental reforms, nor the process of economic liberalisation, faced strong opposition in the Senate. It was expected that the fact that only the extremely wealthy could become members of the Senate would have led to a more conservative body, but, in practice, the politics of both houses did not differ much at all. This does not mean that the Senate had no importance in Dutch politics. For example, the king still tried to use the Senate to block unwelcome legislation but was only successful in a few cases, using his influence to block a law on the laying of railway tracks, for instance. However, he could not prevent the passing of legislation which abolished the death penalty and repealed the tax on newspapers. The number of members loyal to the king decreased rapidly, and the capricious king soon lost interest in politics altogether.

In 1868 , the Senate played a role in mediating a conflict between the liberal majority in the House of Representatives on one side and the king and his conservative government on the other. Despite suffering defeats in Parliament, the king would not let go of his cabinet. He dissolved the House of Representatives twice and threatened to do so a third time. Some senators intervened as mediators, thereby gaining the appreciation of some politicians, especially liberals, for the Senate.

Although the Senate's rejection of a bill would sometimes be criticised, there was no general discontent regarding the institution. From the 1880s onwards, most liberals were in favour of maintaining it so that it could act as a counterweight against the up-and-coming Christian parties. Since the late 1870s, protestant MPs had started to become a political force. In 1879, Abraham Kuyper successfully transformed the movement started by Groen van Prinsterer into a parliamentary faction and political party - the ARP (Anti-Revolutionary Party). At the same time, Catholic MPs broke off from the liberal line and also formed a faction in Parliament. Liberal power suffered slightly. Thus, it was the liberals who supported maintaining the Senate in the debates on constitutional reform in the 1880s, while the ARP and Catholics were in favour of transforming it. They wanted the Senate to become a house of broader social interests, consisting of dedicated delegates, for example, for scientists, employers, and trade unions (Van den Braak 1998).

However, there was no longer any support for the eligibility rules based on income. Eventually, a compromise was reached between the liberal and Christian parties. Membership of the Senate was opened for new groups, firstly by reducing the tax threshold for eligibility and secondly by extending the right to be elected to several high positions, e.g. judges, high-ranking officers, ministers, MPs, mayors of large cities, and professors. The reform was accepted in 1887, the same time as the expansion of suffrage. Now, all male citizens meeting a specific qualification, namely paying a certain amount of rent, having savings, or having passed exams, could become voters. As a part of constitutional reform, the Senate was expanded 
to fifty members. Senators were still elected for terms of nine years, with onethird cycling out every three years.

The emergence of Christian and later socialist parties and the decline of liberal parties complicated politics, especially regarding the distribution of power in both houses. In the years 1888-1917, cabinets would occasionally have a majority in the House of Representatives, while having a minority in the Senate. In the general elections of 1888, the Christian parties, known as 'the coalition', achieved a small majority in the House of Representatives, and the first Christian cabinet was formed - named the Mackay cabinet, after its prime minister. The liberals continued to dominate the Senate. Despite the acceptance in both houses of an important new law on education, which would allow subsidisation of Christian primary schools, the cabinet faced a generally 'hostile' Senate. In the years after 1891, liberals came back into power, but in 1901 the Christian parties again became the largest block and took power, though faced by an opposing majority in the Senate. This was the Kuyper cabinet. In the years between 1888 and 1901, the Christian parties had won more seats in many provincial estates, but the nineyear term of senators slowed down that political shift in the Senate. Nevertheless, a shift in power did occur in some provinces, especially the large province of South-Holland.

When, in 1904, the Senate rejected a bill on higher education, the cabinet dissolved the Senate. The bill would have given graduates of the private (Christian) Vrije Universiteit Amsterdam, founded by Kuyper in 1880, equal rights to graduates of public universities. Liberals rejected the proposal vehemently. Election of all fifty seats in the Senate had the effect Kuyper had hoped for: Christian parties managed to acquire a majority in the Senate. After being issued a second time, the bill achieved a majority in both houses. The 1904 election led to a lasting shift in power. Until the 1960s, Christian parties would continue to dominate the Senate.

After the outbreak of the First World War in 1914, all parties agreed to pause. They also agreed to constitutional reforms to introduce general male suffrage, as well as formally regulating the equal subsidisation of public and private (Christian) schools. The latter issue had caused quite a political crisis at the time and led to a political deadlock between Christian parties on one side and socialist and liberal parties on the other. This 'pacification' of Dutch politics came into effect in 1917. It not only led to an increase in the number of voters but also extended passive suffrage to women. It would take until 1919 for women to obtain active suffrage, and in 1920 the first woman became a member of the Senate.

After the constitutional reforms of 1917, there were no longer specific conditions for eligibility for the Senate. However, the old electoral system for the Senate, which required that potential members be supported by a majority in the States-Provincial, stayed in place. Since Christian parties again benefitted most from the extension of suffrage, they now obtained an overwhelming majority in the Senate (Prakke 1990). It took until 1922 for a new electoral system for the Senate to be introduced, based on proportional representation. All members were to be chosen every four years by all members of the States-Provincial. The weight of the States-Provincial's votes was linked to the number of inhabitants per province. 


\section{8}

Therefore, a vote in the province South-Holland, for instance, counted for much more than a vote in a sparsely populated province, such as Zeeland. Although the connection had never been particularly strong, many senators wanted to keep the connection between provinces and 'their' senators and opposed this idea of proportional representation.

A second, rather far-reaching proposal for reform was that the dissolution of the Senate could be followed by abolishing the States-Provincial, which would lead to new elections for the provincial assemblies. There was fierce resistance against this proposal in the Senate, fearing that it would disturb provincial government. Some also feared that party influence on the composition of the Senate would increase. The proposed electoral system made it possible to calculate the number of seats a party would get in the Senate in advance. Elections would thus become an almost mathematical process. The Senate rejected the bill with a vast majority. The cabinet had to come up with an alternative bill. The idea of dissolving the States-Provincial along with the Senate was left by the wayside and the new electoral system was proposed, consisting of four groups of provinces. Each group, which had no specific regional cohesion, would choose twelve or thirteen members of Senate. North-Holland and Friesland, for example, were tasked with choosing twelve members. The cabinet also proposed reducing the term of office to six years, with election for twenty-five members every three years. That way, there would still be some delay in the manifestation of electoral changes. In practice, this meant that elected States-Provincial were sometimes called to elect senators after only the second year of a three-year term.

Although few MPs and senators were particularly satisfied with this second bill, the necessity to have a new, fairer electoral system by the 1923 election year was more pressing. The second bill was adopted. In 1923, shortly before the new elections were to be held, a bill to implement this constitutional reform as electoral law was accepted as well. The outcome was a system that few approved of and that was, at most, considered 'second best' (Van den Braak 1998).

\section{Members of the Senate}

Given the royal right of appointment in the early nineteenth century, it is not surprising that all members of the Senate in 1815-1848 were from the upper class. Among them were court officials, high-ranking military officers, former ministers, and members of the urban elite and landowners, both from the North and South. Almost all Belgian members were noblemen. The composition of the House of Representatives was clearly very different. The Belgian members of that house included, for instance, various industrialists and several lawyers and judges. Some Northern members were merchants or bankers, but most of them were gentry or local governors. After the Belgians had seceded in 1830, the similarities between the members of both houses grew closer, although the Senate remained more elitist.

The constitutional change of 1848 and the new rules for elections led to major changes in both houses, both in terms of political composition and in the social 
backgrounds of their members. The main intention behind this new electoral system was to ensure that the Senate would not be a copy of the House of Representatives. The States-Provincial was responsible for electing senators, and only the extremely wealthy were eligible. The minimum age for eligibility in the Senate was, however, lowered from 40 to 30 years, making it the same as the minimum age in the House of Representatives. There certainly were some differences, of course. There were more landowners and wealthy merchants among the senators, while the number of lawyers and judges was higher in the House of Representatives. After 1870, there were even some MPs who had been or still were journalists or middle-class merchants. In general, the House of Representatives and the Senate after 1848 did not differ as much as one would have expected. There were even family relations between members of both houses.

As mentioned earlier, the constitutional reform of 1887 brought an end to the exclusive right of the very wealthy to become member of the Senate. New groups were now eligible as well. Most importantly, MPs, some of whom came from the lower class, became eligible. Nevertheless, the electoral system ensured that it was not until 1911 and 1913 that a progressive liberal and a social democrat, respectively, were elected to the Senate. The reform in 1917 brought with it two houses without any formal distinctions with regard to eligibility.

The new electoral system in 1923 greatly increased the similarity of both houses in terms of political composition. The number of social democrats in the Senate, for instance, increased from four to eleven. Among them, as among Catholic and Protestant MPs, there were some trade union leaders and members of the working class. In comparison to the House of Representatives, the number of professors in the Senate was higher. Full-time professors could not become MPs. The House of Representatives had more journalists, party officials, and Protestant clergymen as members. This undoubtedly contributed to a different tone of debate in the two houses but not to different outcomes. A major change in 1923 was that the States-Provincial, as such, no longer elected senators. This appeared to diminish regional representation, but as stated earlier, regional representation was not common before 1923 either. Parties just looked for the provinces where they had the greatest chance of winning. The first socialist senator, Henri Polak, lived in North-Holland but was elected in Friesland. Catholics from Northern provinces had to apply as candidates in the Catholic Southern provinces to stand a chance of winning. The western provinces always dominated the Senate, and that did not change after 1923.

Still, in general, there were major differences in the social composition of both houses before and after 1917. They both became less elitist and soon started to better reflect a highly organised Dutch society, the so-called Verzuiling (compartmentalisation). Under Verzuiling, Dutch society was divided into four major social pillars: Catholic, Protestant, social-democratic, and liberal, each with its own organisation. This division of society lasted until the 1980s.

From the 1960s, distinctions between the Senate and House of Representatives grew again, mainly because of changes to the House of Representatives. After 1960, a process of professionalisation was set in motion. Until then, members of 
both houses combined their political life with a separate profession, such as trade union leader, mayor, alderman, or provincial governor. In the 1960s, MPs more often became full-time professional MPs because of better pay and better work in an increasingly complex government. They simply had to focus on their parliamentary work. Among the MPs, now somewhat younger than before, there were many who had started off their careers in politics, which simultaneously led them to play a more active role in government. This development helped the Senate profile itself as a more distanced institution, with fewer 'politicised' members. To that extent, it was able to play a role as a 'house of reflection'. Sometimes senators even profiled themselves as 'amateur' politicians (which they were not, of course) to emphasise their somewhat greater degree of independence.

In the decades after 1980, the strictly divided Dutch society and its parallel political system gradually disappeared. The socialist and Catholic trade unions merged to a new federation, as did organisations of employers and farmers. The three Christian parties - two Protestant and one Catholic - merged into one, the CDA. Furthermore, society became more secular, and voters became more volatile. This was reflected in the composition of both houses. Representatives of new interest groups emerged, and those of traditional groups declined. The Senate, however, had more elderly members (although a 19-year-old member was elected in 2003), which meant that senators were generally more experienced than MPs. From 1983, parties also started sending more experienced managers to the Senate from sectors such as healthcare, insurance, welfare, and finance. Close connections with the daily practice of the sectors in which legislation had to be implemented helped them bring forward meaningful arguments. Simultaneously, the number of former ministers and leading politicians in the Senate increased.

This all contributed to growing self-confidence and public appreciation of the role of the Senate (Van den Braak 2009). It is not unusual for senators who are members of parties that oppose the existence of the Senate to become convinced advocates of the institute after a while. The combination of all these developments certainly helped the Senate to play a constructive role.

\section{Discussions}

Although liberals initially criticised the Senate, followed by Christian politicians in the 1880s, it was not until the emergence of socialist and radical-liberal politicians that a clear call for abolition was voiced. These politicians opposed the strong position of the Senate and its restricted accessibility. Given the relatively weak position of these groups, however, their proposals stood no chance.

The balance of power seemed to change for only a short period of time. During the revolutionary turmoil of November 1918, after the fall and flight of the German Emperor, who sought refuge in the Netherlands, Dutch socialist leader Pieter Jelles Troelstra believed that a political, nonviolent revolution was imminent. He was soon proved wrong, but centre-right politicians, including the Christian Charles Ruijs de Beerenbrouck cabinet, formed in 1918, were startled. They agreed on social and political reforms which were, as they said, in accordance 
with the spirit of the times. A constituent commission was set up, chaired by the prime minister. Even some conservative liberals questioned the need for a senate in November 1918. One liberal MP said that only the parliamentary clerks would weep at the Senate's grave. Two years later, when everything calmed down, nothing had fundamentally changed. In the parliamentary debates on constitutional reforms, some right-wing MPs were sceptical about the necessity of a senate, but they were equally aware that there was only a very small chance that senators would vote for their own abolition. In the end, the proposal was not even supported by a plain majority, let alone the required two-thirds majority. Those in favour of maintaining the Senate stated that a second reading ('reflection') of bills remained useful.

After 1923, the Senate was almost a political copy of the House of Representatives. Conflicts in which the Senate played a major role were very rare, and only a small number of bills were rejected. The only bill worth mentioning is one in 1927 to approve a treaty with Belgium. In the aftermath of the First World War, relations between the Netherlands and Belgium were disturbed by Belgian accusations of Dutch passivity towards German demands during the war. Dutch foreign minister Herman Adriaan van Karnebeek made efforts to restore good relations, and in 1925, a treaty between the two nations was signed, creating a new connection between the Schelde, a river near Antwerp, and the Rhine, near Rotterdam. A broad protest movement was set up because many feared that the port of Rotterdam would be negatively impacted by this move. Most political parties were divided on the issue. In the House of Representatives, the bill to approve the treaty was accepted by a very small majority, but the Senate rejected it with thirty-three votes against seventeen. Minister Van Karnebeek resigned.

In the eyes of many, the rejection confirmed the necessity of a senate. It did not have to reject many bills, but by doing so, occasionally, it proved its right of existence. The Senate was seen as a valuable slaperdijk (lit. a sleeping dike, a backup dike in case the first dike were to fail). It was essential that there was always a possibility to block a bill in the Senate so that the House of Representatives would not have the final say. One of the other rare cases in which the Senate would again prove its usefulness was in 1968, when a tax bill was put forward to force tenants who lived in relatively cheap housing to move to more expensive homes. The Senate used its veto to safeguard the interests of the middle class, who would have suffered most from that bill. Only three senators supported the bill. A lack of political debate on legislation within the Senate raised questions about the need for this institution, as some saw it as a superfluous delay in the legislative process.

In the years between 1925 and 1965, the position of the Senate was not the subject of much discussion. In the 1950s, some members of a constitutional commission proposed taking away the Senate's right of budget, but no steps were taken to do so. In the 1960s, younger politicians started to question the political system, specifically addressing the formation of a new coalition without new elections after a political crisis. The influence of voters on the formation of government was very limited. Furthermore, the Christian central parties were considered to be too dominant, as they could always form a cabinet with either liberals or social democrats. 


\section{2}

A new, less proportional electoral system and direct elections for the prime minister were proposed in order to increase voters influence. A major objective was a clear division between the political left and right. A new non-ideological party, D66 (lit. Democrats 1966), was established, with constitutional reform as its key issue. Some of these ideas were embraced by the social democrats and by some left-wing Christian politicians. In this political climate, characterised by a call for constitutional change, the existence of the Senate was also put on the political agenda. After the 1967 elections, in which D66 won seven seats, the centre-right De Jong cabinet (1967-1971) set up a new constitutional commission which recommended holding direct elections for the Senate in 1971. Only a minority of the commission favoured abolition.

In the early twentieth century, politicians had already considered altering the Senate's veto into a right to just return a bill. However, parties did not agree upon the question of who would have to make the final decision: the House of Representatives or the Senate. The Senate's right to return bills, without a (final) veto, would undermine its position, but giving the Senate both a right to return and allowing it to retain its veto would strengthen it. After parliamentary discussion in 1975, a motion was adopted that there should be no infringement on the position or rights of the Senate. The motion was put forward by the Christian democrats and supported by liberals and small Protestant parties. This meant the end to all discussion about the Senate. In 1983, the constitution was modernised, but no major changes were made to the system of government.

However, reconfirmation of the Senate's position was not the only outcome of these discussions. From 1983, all members were elected every four years, directly after the elections for the eleven (twelve after 1986) provincial states. As a result, there would now be a clear link between these two elections. All elected provincial deputies now acted as a single electoral college. Several politicians warned that this might cause problems in the future, for there certainly was a risk that national issues would overshadow the provincial elections. National politicians soon understood the importance of the provincial elections, even though they were second-order elections, with turnout being limited to less than fifty per cent on a few occasions. As they were midterm elections, they would function as a sort of poll on government policies.

Some argue that the political role of the Senate had increased because the elections for the States-Provincial - and thus indirectly the elections for the Senate would be dominated by national issues. This is an oversimplification. From the 1980s, Dutch society and the economy started a period of reform and transition. Between 1945 and 1975, the Netherlands had seen a period of economic recovery and growth. A welfare state was established, and legislation did not face much resistance. That, in fact, was the main reason why the Senate did not play a particularly visible role: there was no need for it to do so. The economic crises of the 1970s ended this. After 1980, a neoliberal era started, characterised by privatisation and a limited government role. Austerity, especially in social laws, was unavoidable. Employers' rights came under pressure. 
In order to successfully introduce legislation and decrease public spending after elections, coalition parties had to make firm agreements and tightened discipline among their fractions. By doing so, the role of the House of Representatives as counterweight against the government in the passing of legislation was weakened. The position of the Senate as a chamber of reflection grew stronger because hasty proposals occasionally led to bad legislation in years of crisis (Visscher 1994). Moreover, civilians and organisations turned to the Senate to voice their concerns much more often than in the past. At the same time, parties, mostly on the left, that had pursued the abolition of the Senate 'rediscovered' the political opportunities it offered. Its speaker (1987-1997), Herman Tjeenk Willink, a Labour politician, advocated that a united Senate which scrutinises and judges bills could play a useful role in the political process (Van den Braak 1998). The Senate ought to examine whether new rules were necessary, how they would be implemented, whether there was no disproportionate breach of rights, etc. (Bogdanor 1992). In that way, the Senate could play a positive role in the legislative process and could claim to be an almost apolitical judge of legislation.

\section{Current role of the Senate}

Compared to other senates, the Dutch Senate has a strong position in the legislative process (Knippenberg 2002). All bills that are accepted in the House of Representatives must also be scrutinised by the Senate. It does not have the right of amendment, but it does have a non-restricted veto. In practice, the veto does not seem to cause major problems, because it is not used very often. Bills are only rarely rejected (Eerste Kamer der Staten-Generaal 2019).

Instead, the Senate uses its veto in a more subtle way (Westerveld 2007). By threatening to use it, it can trigger informal adjustments or promises to improve a bill (Van den Berg 1994). Sometimes, government is forced to delay implementing a bill or to vow that existing rights will be guaranteed. Sometimes, government is compelled to agree to evaluate a bill sooner than originally proposed. Only after these promises are made will parties in the Senate show willingness to vote in favour of the bill. In recent years, the number of motions for anchoring the outcome of debates in the Senate has risen and promises made by government to the Senate are officially registered. This practice of expanded influence on legislation is described as 'a disguised right of amendment'. It is an additional right for a house that can formally only say 'yes' or 'no'.

There are several ways in which this right can be reinforced. The Senate can threaten to reject a bill if the cabinet is not willing to propose a new bill to change it (that new bill is called a novelle). This novelle, of course, must first pass the House of Representatives, as it is just like any other 'regular' bill. In general, that house will be willing to cooperate, because if it fails to do so, the law will presumably fail. However, a novelle can only be used to amend a very specific part of the present bill, and it is not applied very often. Sometimes, the Senate conditionally approves a bill. In that case, the government has to promise to amend the new 
bill afterwards, before it comes into force. When the Senate is very critical about a bill, government will sometimes repeal it entirely before proposing a revised version at a later date. Most often, the Senate functions as a sort of marketplace where ministers and senators negotiate about amendments and promises (Van den Berg 1994). If the government has shown sufficient commitment, senators are generally willing to forget about their earlier objections.

Those in favour of a bicameral system know that the Senate should not become an obstacle in the legislative process. One can assume that using the veto too often could undermine the Senate's position. No political system is particularly satisfied with an institution that hinders legislation, and it would certainly prompt discussions about bicameralism. Therefore, the best senators can do is seek to strike a balance: threaten to reject a bill when there is a good chance of success and occasionally - but not too often - use the veto to let government know that victory is never guaranteed. It is not using the veto that matters as much as threatening to do so.

Cooperation between parties (both in government and the opposition) in the law-making process is now more common, with occasional successes. In debates about a new health insurance system in 2006, the health secretary had to make several concessions to the Senate, and the same happened in debates about new legislation on social welfare. A law for a new police organisation could only be implemented after the justice secretary had promised to submit a second law with modifications. Not all parties are always satisfied with the outcome of a debate, and the Senate is not apolitical at all, of course. Its members are politicians, and the government and opposition can play as much of a role in the Senate as they do in the House of Representatives. Political dominance in decision-making remains a fact. Most members of the Senate do agree that the House of Representatives is the primary political power. There is an awareness of the need to be somewhat restrained, but determining which specific situations require restraint is a matter of political consideration.

We inevitability saw this in the years 2011-2017, when the government coalition no longer had a majority in the Senate (Otjes \& Louwerse 2014). Opposition parties are not obliged to vote in favour of government bills. During the second Rutte cabinet (2012-2017), the liberal-Social Democratic coalition did not have a majority in the Senate. Therefore, it had to negotiate with opposition parties to ensure a majority in both houses, with advantageous results for the coalition. By broadening support in the House of Representatives, it could also successfully manage the Senate. Parties in the Senate were compelled to follow the party line of their respective parties, which was determined in the House of Representatives. Senators had to accept these deals without having much chance to use the Senate's usual power.

The need to negotiate for the ruling parties could be explained from the increasing importance of the Senate, but at the same time the outcome confirmed that Senate fractions will mostly follow the judgement of their fellow party members in the House of Representatives. 


\section{Conclusion and implications}

It seems obvious, but the main reason why the Netherlands still has a significant senate is political. It has managed to occasionally reform itself. Although there were some moments at which the Senate seemed to be in jeopardy, there was never any real momentum for it. Dutch politics has always been based on 'wheeling and dealing' and seeking compromise. Government policy in the Netherlands not only has to be vigorously supported but also, preferably, must be well and broadly supported (Timmermans \& Andeweg 2000). Since 1922, no bill has been proposed with the aim of abolishing the Senate (Van den Braak 2000). Discussions about the Senate's continued existence ended as early as 1975 . From the 1980s, a positive and constructive role of the institution had to be accepted by former critics because experience showed that the Senate had survived all attacks on its existence. Opposition parties, especially on the left, were all too keen to use the Senate as a useful institution by which they could obtain a firmer grasp on government policy. Although the Senate was set up as a bulwark, first for the king and, after 1848, more or less for the upper-class, it never was a hindering power. After the period between 1888 and 1918, in which both houses sometimes had opposing majorities, the Senate did not play a very significant role. That 'invisibility' only led to an absence of discontent (Cramer 1990).

New discussions about the role of the Senate began after 2010, when cabinets (led by Mark Rutte) had to deal with a stronger opposition in the Senate. The main question still is this: can it always be justified that an indirectly elected senate overrules decisions taken by the directly elected House of Representatives (Van den Braak 2015)? Some politicians reject such a 'political' role for the Senate. They want the Senate to play a merely non-political role in which guarding the quality of legislation is the main objective. There are, however, two issues with such an approach. First, the Senate is a political body with party politicians as members; second, the line between political and non-political arguments is often very thin. Some members, for instance, can state that a new bill will be hard to implement, while others may see no problems with that at all. A 'technical' judgement can and very often will be influenced by political opinion.

In 2016, a commission was installed and asked to investigate whether the parliamentary system requires improvement and if so, how (Staatscommissie parlementair stelsel 2017). The commission suggested the introduction of a right for the senate to send back bills to the lower house, with suggestion for adjustments. That House then should make a final decision about the bill. There also might be a slight chance that some sort of conciliation procedure for disputes between both houses will be introduced. That could be made possible if the united assembly of both houses is given a new role as mediator. That, too, will need constitutional reform, requiring a two-thirds majority in the second reading.

Such constitutional change would only be necessary if there were a greater chance of political stagnation in a situation where the two houses have opposite majorities, and opposition parties are unwilling to compromise on major issues. The problem, of course, is that nobody knows whether this is a realistic scenario. 
Not only is changing the constitution not a political venture but it also would take several years. It can only be accomplished after elections (the first are in 2021, and after that, probably in 2025). So the Dutch Senate certainly will not be abolished soon, and fundamental changes are not to be expected either. For the future, the Senate will, in all likelihood, remain free from any crises that might jeopardise its continued existence.

\section{References}

Beekelaar, G.A.M. and De Schepper, H. (1992), 'The first chamber in the Netherlands 1815-1848', in: Blom, H.W. et al. (eds.), Bicameralisme. Tweekamerstelsel vroeger en $n u$ (The Hague: Sdu), pp. 279-289.

Blom, H.W. (1992), 'Bicameralism - history - theory - problems', in: Blom, H.W. et al. (eds.), Bicameralisme. Tweekamerstelsel vroeger en nu (The Hague: Sdu), pp. 19-32.

Bogdanor, V. (1992), 'The problem of the Upper House', in: Blom, H.W. et al. (eds.), Bicameralisme. Tweekamerstelsel vroeger en nu (The Hague: Sdu), pp. 411-422.

Broeksteeg J.L.W. (2006), 'De Eerste Kamer als politiek orgaan', in: Berg, J.Th.J., Van den, Broeksteeg L.W. and Verhey, L.F.M. (eds.), Het Parlement - Staatsrechtconferentie (Maastricht: Wolf Legal Publishers), pp. 171-175.

Cramer, N. (1990), 'De Eerste Kamer na 1917 in heroverweging', in: Postma, A. et al. (eds.), Aan deze zijde van het Binnenhof (The Hague: Sdu), pp. 283-344.

De Vries, F. (2000), De staatsrechtelijke positie van de Eerste Kamer (Groningen: Wolters Kluwer).

Eerste Kamer der Staten-Generaal (2019), Feiten en cijfers. Available at: www.eerstekamer. $\mathrm{nl} /$ begrip/feiten en cijfers (accessed 13 March 2019).

Knippenberg, E.T.C. (2002), De Senaat. Rechtsvergelijkend onderzoek naar het House of Lords, de Sénat, de Eerste Kamer en de Bundesrat (The Hague: Sdu).

Otjes, S. and Louwerse, T. (2014), 'A special majority cabinet? Supported minority governance and parliamentary behavior', World Political Science Review 10(2), pp. 343-365.

Prakke, L. (1990), 'Van links naar rechts. De Eerste Kamer van 1887 tot 1917', in: Postma, A. et al. (eds.), Aan deze zijde van het Binnenhof (The Hague: Sdu), pp. 227-265.

Staatscommissie parlementair stelsel (2017), Probleemverkenning. Available at: www. staatscommissieparlementairstelsel.nl/documenten/publicaties/2017/10/18/probleem verkenning-staatscommissie-parlementair-stelsel (accessed 10 March 2019).

Timmermans, A. and Andeweg, R.B. (2000), 'Coalition cabinets in the Netherlands: Still the politics of accommodation?', in: Muller, W.C. and Strøm, K. (eds.), Coalition Governments in Western Europe (Oxford: Oxford University Press), pp. 356-398.

Van den Berg, J.Th.J. (1994), 'De voorstellen van de commissies De Koning en De Jong inzake terugzendrecht, adviescolleges en werkwijze Tweede Kamer', in: Baljé, C.L. (ed.), Vernieuwing en Eerste Kamer (The Hague: Sdu), pp. 69-76.

Van den Braak, B.H. (1998), De Eerste Kamer. Geschiedenis, samenstelling en betekenis 1815-1991 (The Hague: Sdu).

Van den Braak, B.H. (2000), 'Met de tijd meegegaan. Eerste Kamer van bolwerk van de Kroon tot bolwerk van de burgers', in: Van Baalen, C.C. et al. (eds.), Jaarboek Parlementaire Geschiedenis (Nijmegen-The Hague: Centrum Parlementaire GeschiedenisSdu), pp. 44-59. 
Van den Braak, B.H. (2009), 'Geen zelfreflectie, maar zelfbewustzijn. De Eerste Kamer in de periode 1995-2009', in: Van Baalen, C.C. et al. (eds.), Jaarboek Parlementaire Geschiedenis (Nijmegen-The Hague: Centrum Parlementaire Geschiedenis-Sdu), pp. 85-95.

Van den Braak, B.H. (ed.) (2015), Het “probleem” Eerste Kamer. Visies op de toekomstige rol van de Senaat, (The Hague: Montesquieu Institute).

Visscher, G. (1994), Parlementaire invloed op wetgeving. Inventarisatie en analyse van de invloed van de beide Kamers der Staten-Generaal op de wetgevende activiteiten van de kabinetten-Marijnen tot en met -Lubbers I (The Hague: Sdu).

Westerveld, M. (2007), 'Hoe zinvol is de Eerste Kamer? Enige reflecties naar aanleiding van het Preadvies 'Nut en doel van het tweekamerstelsel', in: Van den Berg, J.Th.J., Broeksteeg, J.L.W. and Verhey, L.F.M. (eds.), Het Parlement - Staatsrechtconferentie 2006 (Maastricht: Wolf Legal Publishers), pp. 157-170. 